\title{
Genetic, epigenetic and microbiome characterisation of an earthworm species (Octolasion lacteum) along a radiation exposure gradient at Chernobyl
}

Article

Accepted Version

Creative Commons: Attribution-Noncommercial-No Derivative Works 4.0

Newbold, L. K., Robinson, A., Rasnaca, I., Lahive, E., Gweon, H. S., Lapied, E., Oughton, D., Gashchak, S., Beresford, N. A. and Spurgeon, D. J. (2019) Genetic, epigenetic and microbiome characterisation of an earthworm species (Octolasion lacteum) along a radiation exposure gradient at Chernobyl. Environmental Pollution, 255 (Part 1). 113238. ISSN 0269-7491 doi:

https://doi.org/10.1016/j.envpol.2019.113238 Available at https://centaur.reading.ac.uk/87026/

It is advisable to refer to the publisher's version if you intend to cite from the work. See Guidance on citing.

Published version at: http://dx.doi.org/10.1016/j.envpol.2019.113238

To link to this article DOI: http://dx.doi.org/10.1016/j.envpol.2019.113238

Publisher: Elsevier

All outputs in CentAUR are protected by Intellectual Property Rights law, including copyright law. Copyright and IPR is retained by the creators or other copyright holders. Terms and conditions for use of this material are defined in 
the End User Agreement.

www.reading.ac.uk/centaur

\section{CentAUR}

Central Archive at the University of Reading

Reading's research outputs online 
1 Genetic, epigenetic and microbiome characterisation of an earthworm species

2 (Octolasion lacteum) along a radiation exposure gradient at Chernobyl

5 Newbold, Lindsay K. ${ }^{a}{ }^{*}$, Robinson, Alex ${ }^{a}{ }^{*}$, Rasnaca, I. a, Lahive, Elma. ${ }^{a}$, Gweon, H. Soon ${ }^{a, b}$,

6 Lapied, Emmanuel c, Oughton, Deborah ' , Gashchak, Sergey d, Beresford, Nicholas A. e, 7 Spurgeon, David J. ${ }^{a, t}$.

$10{ }^{a}$ Centre for Ecology and Hydrology, MacLean Building, Benson Lane, Wallingford, Oxon, OX10 11 8BB, UK.

13 b School of Biological Sciences, University of Reading, Whiteknights, Reading, Berkshire, RG6 $146 \mathrm{AH}, \mathrm{UK}$.

$16{ }^{\mathrm{c}}$ Centre for Environmental Radioactviity, Norwegian University of Life Science, 1430 Aas, Norway 17

$18{ }^{\mathrm{d}}$ Chornobyl Center for Nuclear Safety, Radioactive Waste and Radioecology, Slavutych, Kiev 19 Region, Ukraine

21 e NERC Centre for Ecology \& Hydrology, Lancaster Environment Center, Library Av., Bailrigg, 22 Lancaster LA14AP, UK

25 * The authors contributed equally to this work

$26{ }^{\dagger}$ Author to whom correspondence should be addressed David Spurgeon, Centre for Ecology and 27 Hydrology, MacLean Building, Benson Lane, Wallingford, Oxon, OX10 8BB, UK. email: 28 dasp@ceh.ac.uk 


\section{Abstract}

30 The effects of exposure to different levels of ionising radiation were assessed on the genetic,

31 epigenetic and microbiome characteristics of the "hologenome" of earthworms collected at sites

32 within the Chernobyl exclusion zone (CEZ). The earthworms Aporrectodea caliginosa (Savigny,

33 1826) and Octolasion lacteum (Örley, 1881) were the two species that were most frequently found

34 at visited sites, however, only $O$. lacteum was present at sufficient number across different

35 exposure levels to enable comparative hologenome analysis. The identification of morphotype $O$.

36 lacteum as a probable single clade was established using a combination of mitochondrial

37 (cytochrome oxidase I) and nuclear genome (Amplified Fragment Length Polymorphism (AFLP)

38 using Mspl loci). No clear site associated differences in population genetic structure was found

39 between populations using the AFLP marker loci. Further, no relationship between ionising

40 radiation exposure levels and the percentage of methylated loci or pattern of distribution of DNA

41 methylation marks was found. Microbiome structure was clearly site dependent, with gut

42 microbiome community structure and diversity being systematically associated with calculated

43 site-specific earthworm dose rates. There was, however, also co-correlation between earthworm

44 dose rates and other soil properties, notably soil $\mathrm{pH}$; a property known to affect soil bacterial

45 community structure. Such co-correlation means that it is not possible to attribute microbiome

46 changes unequivocally to radionuclide exposure. A better understanding of the relationship

47 between radionuclide exposure soil properties and their interactions on bacterial microbiome

48 community response is, therefore, needed to establish whether these the observed microbiome

49 changes are attributed directly to radiation exposure, other soil properties or to an interaction

50 between multiple variables at sites within the CEZ.

51

52 Capsule: Selected earthworm hologenome traits (e.g. gut microbiome) are potentially influenced

53 by radiation exposure, but also confounding soil property variables

55 Keywords: Radioecology, ${ }^{137}$ Caesium, Earthworm, DNA methylation, Microbiome, 


\section{Introduction}

57 The Chernobyl nuclear accident on April $26^{\text {th }} 1986$ was responsible for a large-scale release of

58 radionuclides into the surrounding ecosystem, resulting in long-term exposure of the local and wider environment. Exposure to radioactivity in controlled, high dose laboratory studies has been

60 shown to have effects on soil invertebrate species including earthworms (Hertel-Aas et al., 2007;

61 Rusin et al., 2019; Sowmithra et al., 2015), springtails (Nakamori et al., 2008) and nematodes

62 (Dubois et al., 2019; Lecomte-Pradines et al., 2017). Further, research on the long-term effects of

63 ionising radiation in the surrounds of the former power station, now known as the Chernobyl

64 Exclusion Zone or CEZ, have provided information on the physiological and ecological responses

65 of individuals, populations and ecosystems to chronic radiation exposure (see Beresford et al.,

66 2016; Geras'kin et al., 2008; Hinton et al., 2007; Lourenco et al., 2016). Despite these studies,

67 there is a lack of consensus on the long-term effects of radiation on wildlife in the CEZ, with some 68 studies suggesting wide-scale impacts and others limited effects (Beresford et al., 2019b). Further

69 work is, therefore, needed to understand how radiation exposure affected soil organisms, especially under long-term chronic exposure scenarios.

72 The soil was one of the main sinks for radionuclides released by the Chernobyl accident. The 73 initially high levels in CEZ soils were shown to alter soil invertebrate population sizes and 74 community structure (Krivolutsky, 1996). For example, reduced recruitment rates of the earthworms Aporrectodea caliginosa and Dendrobaena octaedra (Savigny, 1826) resulted in a population decline in contaminated forest sites (Krivolutzkii et al., 1992). Over time, however, earthworm populations at sites in the CEZ showed some recovery, such that within 3 years of the accident, immature/adult ratios and overall earthworm biomass in the previously impacted sites

79 no longer differed from that in uncontaminated areas (Krivolutsky, 1996). Despite this rebound, 80 species diversity has, however, remained lower at some sites (Geras'kin et al., 2008). This initial 81 decline and recovery of earthworm populations in the CEZ in response to acute exposure may 82 provide only a limited picture of potential response trajectory of earthworms to exposure which may also encompass chronic effects on traits relevant for long-term individual physiology and 
84 population dynamics. For example, in a review of the impacts of the 1957 Kyshtym (Russian

85 Urals) accident, reports indicate that soil invertebrate communities had not been restored at a contaminated site (the main contaminant being $90 \mathrm{Sr}$ ) c. 30 years after the accident (see Zaitsev

87 et al., 2014). Given the low dispersal rates (e.g. of the order of 5-10 m a-1 for earthworms which 88 may limit recolonization potential (Marinissen and Vandenbosch, 1992), such a long-term impact 89 of an acute radiation event would seem plausible.

91 The decline and potentially ongoing change for earthworm populations observed at some CEZ 92 sites in the aftermath of the accident raises fundamental questions regarding the potentially 93 adaptive mechanisms by which these organisms may respond to ongoing chronic exposure (as 94 reviewed by Geras'kin et al., 2008). One possibility may lie in population recovery from a low 95 starting density as exposure abates through radioactive decay and radionuclide transport to 96 deeper soil layers. However, even within this scenario, the selection of tolerant individuals leading 97 to the development of an adapted population may also play a role. At Chernobyl, both plant and fungal species have been shown to develop tolerance to radioisotope exposures (Boubriak et al.,

99 2008; Egorova et al., 2015). However, despite evidence for the development of tolerance in 100 earthworms to other pollutants (Fisker et al., 2013; Kille et al., 2013; Langdon et al., 2003), genetic 101 adaptation to radionuclide exposure in this taxa has yet to be clearly established. Adaptation to 102 adverse conditions can result both from phenotypic plastic responses, such as changes in gene 103 expression mediated through modifications in the epigenetic gene regulation, as well as more 104 classically through the selection of traits associated with tolerance. Additionally, changes in the 105 structure and associated function of the host-microbiome can also play a role (Pass et al., 2015). 106

107 The concept of the "hologenome" recognises that changes in the regulation/activity of the genes 108 of the organism itself and changes in the community and functional activity of mutualistic 109 (microbial) communities can in combination contribute to the overall development of adapted 110 phenotypes (Bordenstein and Theis, 2015). To assess how different components of the 111 hologenome respond to radiological exposure (and other environmental co-variables), we here 
112 measure genetic, epigenetic and gut microbiome changes occurring in earthworms (predominantly

113 Octolasion lacteum) collected from multiple sites along a contamination gradient in the CEZ.

114 Genetic trait analysis was undertaken using cytochrome oxidase 1 (COI) sequencing and the

115 measurement of nuclear sequence polymorphisms using AFLP analysis using one restriction

116 enzyme, epigenetic traits were assessed by DNA methylation profiling using methylation sensitive

117 AFLP (meAFLP) conducted by comparing the first AFLP profile to those obtained using a second

118 DNA methylation sensitive restriction enzyme. Gut microbiome structure was quantified using 16S

119 rRNA loci sequencing. These analyses allow us to test the hypothesis that different genetic,

120 epigenetic and microbiome traits of the hologenome show radiation exposure level dependent 121 changes. 


\section{Materials and methods}

124 An pilot field trip to the Chernobyl Exclusion Zone (CEZ) was carried out in October 2014 to identify

125 the earthworm species present within the zone. Twenty sites representing dominant habitats

126 (grasslands, woodlands, wetlands) were visited. Qualitative sampling collected earthworms from

127 a $50 \mathrm{~m} \times 50 \mathrm{~m}$ area over a $2 \mathrm{~h}$ search period. This initial survey indicated that earthworms are

128 relatively uncommon in the CEZ. Indeed, many sites lack this taxon. This limited distribution is

129 likely due mainly to the sandy, low $\mathrm{pH}$, low organic matter nature of the soils present, which are

130 known to be unfavourable for earthworms (Edwards, 2004; Ouellet et al., 2008). Where

131 earthworms were found, they were usually associated with the margins of water bodies,

132 marshlands or in improved soils, such as the gardens of abandoned communities. Based on this

133 information, a second field trip was carried out in October 2016 to collect earthworms of one or

134 more species systematically from sites ranging in expected radionuclide exposure from

135 background to relatively high, with wetlands identified as the main habitats for sampling.

137 During the second field campaign, six earthworm species, Eiseniella tetraedra (Savigny, 1826), 138 Eisenia fetida (Savigny, 1826), O. lacteum, Lumbricus rubellus (Hoffmeister, 1843), A. caliginosa 139 and Aporrectodea rosea (Savigny, 1826) were found at nine sampled sites. Three of these species

140 (E. fetida, L. rubellus and A. rosea) were collected from a limited number of sites giving insufficient 141 variation in radioactivity exposure for the collected specimens. Although E. tetraedra was collected 142 from five sites that covered different radioactivity exposure levels, densities were very low limiting 143 statistical power. Only, O. lacteum was found in sufficient, although sometimes at low, numbers 144 across multiple sites with measured and modeled radiation exposure levels ranging from 145 background to high. Therefore, this species has been selected for the genetic, epigenetic and 146 microbiome trait analyses. It should, however, be noted that due to challenges in distinguishing 147 between species based only upon morphology, additional genetic marker analysis was applied to 148 a further earthworm species ( $A$. caliginosa) in order to corroborate in field taxonomic identity. At 149 each site, effort was made to collect multiple individuals per site within the restricted timeframe 150 (as Governed by access permissions) that was available for collection. This was often challenging 
151 as even at sites where earthworms were present, densities were often low. Each individual 152 collected was treated thereafter as a separate biological replicate for that sample location.

154 Live earthworms were collected from the soil by digging and hand sorting. Individuals were 155 maintained on own site soil for transfer to a local working area for identification and subsequent 156 dissection for tissue samples. Due to the unique conditions presented by the sample site (remote 157 location, sampling period limitations, and minimal facilities) an on-site protocol was used for 158 sampling and tissue preservation. All earthworms were initially weighed, surface cleaned in 159 phosphate-buffered saline to remove any adhering soil particles. The position of the worm's 160 clitellum was used to divide the tissue into anterior (including the clitellum) and posterior section 161 samples. To preserve sample integrity, tissues intended for later DNA extraction were cut into 162 small pieces and placed in 1:10 ratio of sample weight to DNA/RNA shield ${ }^{\mathrm{TM}}$ lysis and preservation 163 buffer (Zymo Research, Irvine, USA). Samples were lysed in the field using the super FastPrep ${ }^{\mathrm{TM}}$ 164 handheld homogenizer and Lysing Matrix E (both from MP Biomedicals, Eschwege, Germany). Lysed samples and sampled soils (to $10 \mathrm{~cm}$ depth) were transported back to the main laboratory 166 and stored at $-20^{\circ} \mathrm{C}$ prior to DNA extraction. The soils sampled at each site were also used for 167 radionuclide (Cs-137, Sr-90, Am-241, Pu-total isotope) activity measurements for dosimetry 168 calculation. This augmented the simple measurement of air dose rate made in-situ at each site.

\section{Radionuclide Measurement and dosimetry approach}

171 Soil and earthworm ${ }^{137} \mathrm{Cs}$ concentrations were measured using gamma spectrometry (Ge and Nal 172 scintillation detectors, Canberra). Whole earthworm and earthworm soil gut measurements of $173{ }^{137} \mathrm{Cs}$ were carried out when samples were available. Soil ${ }^{90} \mathrm{Sr}$ concentrations were determined 174 using beta spectrometry of the daughter nuclide ${ }^{90} \mathrm{Y}$, and ${ }^{241} \mathrm{Am}$ using low energy gamma 175 spectrometry. $\mathrm{Pu}$ concentrations (total Pu-isotopes: ${ }^{238} \mathrm{Pu},{ }^{239} \mathrm{Pu},{ }^{240} \mathrm{Pu}$ ) were determined after 176 sample dissolution (65\% $\mathrm{HNO}_{3}$ ), anion exchange separation (BioRad AG $1 \times 8,100-200$ mesh) 177 and co-precipitation using ${ }^{242} \mathrm{Pu}$ added as a yield tracer. These samples were then counted using 
178 a planar ion implanted silicon detector. All methods were calibrated against standards and 179 counting errors were typically $<3 \%$ for ${ }^{90} \mathrm{Sr},<7 \%$ for ${ }^{137} \mathrm{Cs}$ and $<20 \%$ for the $\mathrm{Pu}$ isotopes.

181 Controversies in interpreting results from field-based radioecology studies can arise due to an

182 incomplete assessment of actual organism exposure (Bonzom et al., 2016). Thus, while external 183 dose rates can provide an indication of exposure at sites, they usually underestimate actual doses 184 received by an organism, since they do not include the contribution from internalised 185 radionuclides. Therefore, we chose to estimate exposure as weight absorbed dose rate, which 186 includes the contribution of all radiation types (alpha, beta and gamma emitters) from all exposure 187 pathways (internal and external), as opposed to just ambient external dose rates measured with 188 dosimeters (e.g. Moller and Mousseau, 2009; Uematsu et al., 2015). The approach to dosimetry 189 assessment for all sites used a stepwise approach that: 1) recorded air dose rates and ranges 190 (mGy/hr) at the soil surface and $1 \mathrm{~m}$ above ground at each collection sites; and 2) used the 191 measured activity levels in soils to estimate the relative internal and external dose rate 192 contributions of each radionuclide to earthworm exposure. Dosimetry modelling was carried out 193 within a tier 3 assessment using the ERICA tool, a software system that has a structure based 194 upon the tiered approach to assessing the radiological risk to terrestrial, freshwater and marine 195 biota (Brown et al., 2008), using the creation of organisms (different earthworm sizes) and site196 specific data. Measured tissue concentrations of ${ }^{137} \mathrm{Cs}$ were used to calculate internal dose rates, 197 while the ERICA default transfer ratios for earthworms were used for the other radionuclides (Popic 198 et al., 2012). Weighting factors of 1,3 and 10 were used for gamma and beta $>10 \mathrm{keV}$, beta $<10$ $199 \mathrm{keV}$ and alpha radiation, respectively. Based on the radionuclide concentration in soil and the 200 sampled organism, external and internal dose rates $\left(\mu G y h^{-1}\right.$ ) were calculated and used to 201 determine total weight absorbed dose rates.

\section{DNA extraction}

204 Following sample return to the main research laboratory, a protocol was developed which enabled 205 the co-extraction of the earthworm and microbial DNA from the tissue and gut microbiome 
samples. Preserved tissue lysate was extracted using the Zymo research ZR-96 soil microbe DNA

207 kit $^{\mathrm{TM}}$, with the following modifications. Prior to DNA extraction samples were thawed, then

208 incubated with $2 \mu \mathrm{l}$ proteinase $\mathrm{K}$ (Promega) for 1 hour at $20^{\circ} \mathrm{C}$. All samples underwent a further 209 mechanical lysis step on a fast prep 24 (MP Biomedicals) at $5 \mathrm{k}$ for $30 \mathrm{sec}$. Lysed samples were 210 centrifuged at $2100 \mathrm{~g}$ for 5 minutes and $250 \mu \mathrm{l}$ of lysate combined with $750 \mu \mathrm{l}$ soil binding buffer.

211 All further steps were carried out according to manufacturer's protocol. Anterior (head) and 212 posterior (tail) samples were extracted separately for analysis of earthworm genomic and 213 microbiome traits, respectively. Large worms often contained more tail tissue than optimal for each 214 lysis tube, where this was the case, the available tissue was spread across a number of tubes, 215 from all of which DNA was extracted. To ensure that the entire microbiome was represented 216 accurately, the results from all assessment for each individual worm were pooled.

218 Genotyping

219 DNA samples extracted from the body wall from the anterior proportion of the earthworm were 220 used for the corroboration of field species identification. Approximately $20 \mathrm{ng}$ of DNA template 221 was used to amplify $\sim 710$ bp region of the mitochondrial cytochrome oxidase subunit I (COI) gene, 222 in a $50 \mu \mathrm{l}$ total reaction, following the addition of; $0.4 \mu \mathrm{l}$ of taq polymerase (Sigma), $1 \mu \mathrm{l}$ of $10 \mu \mathrm{M}$ $223 \mathrm{dNTP} \operatorname{mix}$ (Bioline), $0.5 \mu \mathrm{l}$ bovine serum albumin (New England Biolabs), and $0.5 \mu \mathrm{l}$ of $100 \mu \mathrm{M}$ 224 primers LCOI1490F and HC02198R (Folmer et al., 1994). Amplification conditions were as 225 follows: $95^{\circ} \mathrm{C}$ for $2 \mathrm{~min}$, then 35 cycles of $95^{\circ} \mathrm{C}$ for $1 \mathrm{~min}$., $40^{\circ} \mathrm{C}$ for $1 \mathrm{~min}$, and $72^{\circ} \mathrm{C}$ for $1: 30 \mathrm{~min}$, 226 with a final extension at $72{ }^{\circ} \mathrm{C}$ of $10 \mathrm{~min}$. PCR products were electrophoretically analysed and then 227 purified using the ZR-96 DNA Clean-up kit ${ }^{\mathrm{TM}}$ (Zymo research). Purified PCR product was diluted 228 at a 1:10 ratio and $1 \mu \mathrm{l}$ used separate $\mathrm{F}$ and $\mathrm{R}$ sequencing reaction carried out using $1 \mu \mathrm{l}$ BigDye ${ }^{\mathrm{TM}}$ 229 terminator $\vee 3.1$ reaction mix (Applied Biosystems, USA), $1.5 \mu$ l BigDye ${ }^{\mathrm{TM}}$ terminator $\bigvee 3.1$ buffer, $2301 \mu \mathrm{l}$ of $3.2 \mu \mathrm{M}$ primer solution, on an Applied Biosystems 3730 genetic analyser. Because of 231 inconsistent amplification using LCOI1490F and HC02198R, a custom additional internal 232 sequencing primer was designed and included for this study COI_lumbricF_seq (5'233 TACAGCCACGCATTCGTTA-3'). Sequencing reactions were purified using Big Dye ${ }^{\circledR}$ 
234 Xterminator $^{\mathrm{TM}}$ purification kit (Applied Biosystems, USA) and sequenced using $\mathrm{ABI} \mathrm{PRISM}^{\circledR}$

235 BigDye v3.1 Terminator technology (Applied Biosystems). Resultant sequences were base called,

236 quality checked and assembled using Sequencher V. To act as suitable phylogenetic outgroups

237 resultant contigs were aligned using ClustalW with reference COI sequences sourced from the

238 barcode of life (BOLD) database, NCBI genebank and unpublished reference sequences from

239 native worms sourced in UK (OS1). Optimal likelihood settings were determined to be TVM+G

240 through the implementation of the Akaike Information Criterion in JModelTest V2.17 (Darriba et

241 al., 2012; Posada, 2008). PAUP4b8 was used to generate a Neighbour Joining (NJ) tree using the

242 likelihood criterion (with optimal settings), and bootstrap support values for 1000 replicates. The

243 resultant tree (OS2) was used to determine the taxonomic affiliation of each earthworm and

244 identities corroborated via inclusion in the nearest supported cluster. For O. lacteum, a set of

245 successfully amplified product sequences clustered with 0 . lacteum $\mathrm{COI}$ sequences available

246 from BOLD within the constructed phylogenetic tree, supporting the morphological identification

247 for these individuals. For a remaining set of 0 . lacteum individuals (38 of 72 individuals),

248 amplification of the COI gene failed, despite best efforts to optimize template, primers and reaction

249 conditions for PCR. Hence, support for the morphospecies identification for these individuals was

250 not achieved through $\mathrm{COI}$ sequencing. For these samples a combination of onsite morphological

251 taxonomy and distinct species separation through AFLP profile (see Supplementary Fig. 1) was

252 used to verify species identity.

254 Microbiome characterisation

255 Approximately 20-30 ng of template DNA collected from samples was amplified using Q5 High

256 Fidelity Polymerase (New England Biolabs, Hitchin, UK), each sample reaction include a unique

257 barcode-primer combination to allow separation of sequences associated with the different

258 individuals (Kozich et al., 2013). Amplification conditions consisted of 25 cycles of an initial 30s, a

$25998^{\circ} \mathrm{C}$ denaturation step, followed by annealing phase of 30 s at $53^{\circ} \mathrm{C}$, and a final extension step

260 lasting $90 \mathrm{sec}$ at $72^{\circ} \mathrm{C}$. Primer sequence was based on the universal bacterial primer sequence

261 combination 341F and 806R, producing amplicons of $\sim 550$ bp spanning the V3-V4 hypervariable 
regions of the $16 \mathrm{~S}$ small subunit ribosomal RNA gene (herein, 16S rRNA gene). PCR Products were normailsed using Sequalprep normalisation plates (Invitrogen, Carlsbad, CA, USA) and the resultant amplicon library was sequenced at a concentration of $5.4 \mathrm{pM}$ with a $0.6 \mathrm{pM}$ addition of

265 Illumina generated PhiX control library. Sequencing was performed on an Illumina MiSeq platform 266 using V3 chemistry (Illumina Inc., San Diego, CA, USA).

Sequenced paired-end reads were joined using VSEARCH (Rognes et al., 2016), quality filtered using FASTX tools (hannonlab.cshl.edu), length filtered with the minimum length of $300 \mathrm{bp}$, presence of PhiX and adapters were checked and removed with BBTools (jgi.doe.gov/data-andtools/bbtools/), and chimeras were identified and removed with VSEARCH_UCHIME_REF

272 (Rognes et al., 2016) using Greengenes Release 13_5 (at 97\%) (DeSantis et al., 2006). Singletons 273 were removed and the resulting sequences were clustered into operational taxonomic units 274 (OTUs) with VSEARCH_CLUSTER (Rognes et al., 2016) at 97\% sequence identity (Tindall et al., 2010). Representative sequences for each OTU were taxonomically assigned by RDP Classifier with the bootstrap threshold of 0.8 or greater (Wang et al., 2007) using Greengenes Release 13_5 277 (full) (DeSantis et al., 2006) as the reference. Unless stated otherwise, default parameters were used for the steps listed. The raw sequence data reported in this study have been deposited in 279 the European Nucleotide Archive under accession number ERS3594341-ERS3594509.

After quality filtering a total of 13725096 sequences were rarefied to an even depth within the phyloseq package (McMurdie and Holmes, 2013). To visualise the relationship between Miseq community profiles from differing sample sites, nonmetric multidimensional scaling (NMDS) was 284 performed using the 'ordinate' function, based on dissimilarities calculated using the Bray-Curtis 285 index. Changes in bacterial diversity related to mean dosage were assessed using Fishers log 286 series [alpha], as this is largely unaffected by sample size and independent if individuals (N) $287>1000$. Diversity was analysed in relation to potential environmental drivers relevant for sites in 288 the CEZ including soil $\mathrm{pH}$, loss on ignition and the calculated dose rates. 
Genetic and epigenetic characterisation using dual restriction enzyme AFLP

291 A dual restriction enzyme based meAFLP protocol was optimised to assess genetic markers and

292 DNA methylation at these sites. The protocol used is based on parallel use of methylation- and 293 non-methylation-sensitive restriction enzymes (Hpall and Mspl) to treat DNA samples prior to 294 primer ligation and amplification (Xiong et al., 1999). Initially extracted genomic DNA is digested 295 with $E c o R I$ and then there is a second digestion step conducted for an aliquot of this sample using 296 either the restriction enzymes Mspl or Hpall. Both Hpall and Mspl recognize a CCGG sequence. 297 Mspl is able to cut methylated recognition sites (as well as unmethylated ones) thereby providing 298 an assessment of relevant genetic polymorphism. In contrast, Hpall is unable to cut at such 299 locations when they are methylated (i.e. only unmethylated recognition sites are cut) which by 300 comparing to Mspl profiles provides an assessment of epigenetic DNA methylation status.

302 The meAFLP analysis was conducted in duplicate for all $O$. lacteum and $A$. caliginosa using 303 selective primers for the PCR reactions and analysis on an Applied Biosystems 3130 analyser 304 (Andre et al., 2010). The presence or absence of fragments was scored on chromatograms using 305 GeneMapper Genotyping Software 1.5. Profile bin widths were checked and manually adjusted to 306 encompass all detected peaks. To differentiate signal from background, a Fluorescence Unit (FU) 307 threshold of 40 units was used for a presence/absence binary matrix. All peaks were manually 308 checked for inclusion in analysis. Rare alleles differing only in one individual were initially deleted 309 from the data set. The total number of loci included in the analysis was 202. Fragments were 310 scored as follows: non-methylated state if present in both EcoRI-Hpall and EcoRI-Mspl products 311 (1/1); methylated state if present in either EcoRI-Hpall (1/0) or EcoRI-Mspl (0/1) products (either 312 internal cytosine methylation $(0 / 1)$ or hemimethylation $(1 / 0))$ or absent $(0 / 0)$. Fragments were 313 classified as "methylation-susceptible loci" if the observed proportion of methylated scores $(1 / 0$, $3140 / 1$ and 0/0) and "non-methylation fragments". Principal coordinates (PCO) analysis was also used 315 to visualise the genetic relationship between individuals using GenAIEx ver 6.4.1 (Srut et al., 316 2017). Site and also potential earthworm strain effects were assessed using the site principal 317 component scores (PCoA1 and PCoA 2) after verification for normality using the Kolmogorov- 
318 Smirnov test. Tests were conducted using ANOVA with site and potential strain differences as 319 factors. 
321 Earthworm distribution, collection and identification by COI barcoding

322 Morphotype 0 . lacteum were collected in sufficient numbers ( $\geq 3$ individuals per site) across five 323 sites covering measured surface dose rates from $0.12-12 \mu \mathrm{Gy} / \mathrm{h}$. All sampled locations yielding

324 O. lacteum were associated with wetland or marshland habitats (Table 1). Morphotype $A$. 325 caliginosa were collected from three sites covering dose rates from 0.12 - $8 \mu \mathrm{Gy} / \mathrm{h}$. However, all 326 but one earthworm came from sites with exposure levels $<0.2 \mu \mathrm{Gy} / \mathrm{h}$. This one $A$. caliginosa 327 collected at site M2: Forest Lake 2 was the only individual to co-occur with 0 . lacteum, indicating 328 an almost completed segregation of the two species across visited sites in the CEZ (Table 1).

330 To confirm the field based morphological identifications, COI gene sequencing was conducted for 331 all individuals to provide a mitochondrial genotype for comparison with previously published 332 sequences for the two species. For the morphotype $A$. caliginosa, the phylogenetic analysis 333 indicated that all amplified sequences clustered with the $A$. caliginosa COI sequences available in 334 the BOLD database. This correspondence supports the morphotype identification of the 335 individuals as $A$. caliginosa. For $O$. lacteum, a set of successfully amplified product sequences 336 clustered with 0 . lacteum $\mathrm{COI}$ sequences available from BOLD within the constructed 337 phylogenetic tree, supporting the morphological identification for these individuals (Supplementary 338 Fig. 2). For a remaining set of 0 . lacteum individuals (38 of 72 individuals), amplification of the 339 COI gene failed, despite best efforts to optimize primers and reaction conditions for PCR. Hence, 340 support for the morphospecies identification for these individuals was not achieved through COI 341 sequencing (see methods). Fortunately, the nuclear genomic loci analysed using the meAFLP 342 method could, however, be used to confirm species identity for these individuals (see below).

344 Soil analysis and dosimetry modeling

345 Measured soil ${ }^{137} \mathrm{Cs},{ }^{90} \mathrm{Sr},{ }^{241} \mathrm{Am}$ and Pu-total, and earthworm gut ${ }^{137} \mathrm{Cs}$ were close to or below 346 detection limits in all control sites and were highest at the H1 Glubokya Marsh site (Table 2). For 347 modeling the transfer of radionuclides to earthworm tissues at CEZ sites, the external irradiation 
348 from ${ }^{137} \mathrm{Cs}$ dominates the exposure profile independent of site (Fig. 1), with internal ${ }^{241} \mathrm{Am}$ 349 representing the next largest dose rate contributor (assuming a radiation weighting factor of 10).

350 The contribution of radionuclides to dose rates were similar across sites (e.g. Fig. 1a/b). Total 351 median modeled dose rates projected for earthworms across the gradient of sites ranged from

3520.09 to $45 \mu \mathrm{Gy} / \mathrm{h}$, these values being correlated the with ambient dose rates, albeit at a factor of

353 2-3 times higher. The quoted internal dose rates represent only the contribution from actual 354 transfer across the gut or skin to the tissues, although the soil in the gut will act as an additional 355 source of exposure. For ${ }^{137} \mathrm{Cs}$, this consideration makes little difference to the total dose rate 356 experienced. There could be a localised dose from ${ }^{90} \mathrm{Sr}$ to the gut surface, but within one order of 357 magnitude of the estimated internal dose rate, although localised dose may be similar. The 358 dominance of external exposure due to ${ }^{137} \mathrm{Cs}$ and the relative contributions of the different 359 radionuclides to internal dose are in agreement with dose estimates based upon radionuclide 360 activity concentrations measured in earthworms (Lumbricidae) and soil sampled from the Red 361 Forest (CEZ) in 2014 (Beresford et al., 2019a).

363 Earthworm size has a relatively small influence on modeled dose rates, with slightly lower ${ }^{90} \mathrm{Sr}$ 364 dose rates in small earthworms, which is expected from differences in absorption and attenuation.

365 At the most highly contaminated sites (H1 Glubokya Marsh), measured activity concentrations in 366 the gut soil of individual earthworms $(29-53 \mathrm{~Bq} / \mathrm{g})$ showed good agreement with the levels 367 measured in the top $10 \mathrm{~cm}$ of soil $(49-86 \mathrm{~Bq} / \mathrm{kg})$. These observations support the modeling 368 predictions that individuals at this site are more highly exposed than earthworms from the other 369 sampled locations.

371 Site soil $\mathrm{pH}$ range from mildly acidic (4.67) at the $\mathrm{H} 1$ Glubokya Marsh site with the highest 372 earthworm dose rate to close to neutral $(6.23$ and 6.66$)$ at two of the low dose rate sites $(\mathrm{C} 1$ 373 Glinka, C3 Chernobyl Garden). Soils contained between 4.5 and $15.6 \%$ organic matter as 374 measured by loss on ignition, the site with the highest dose rate having the highest value which 375 was almost double that any other site (Table 2). The calculated dose rate was significantly 
negatively correlated with soil $\mathrm{pH}($ Pearson correlation $-0.86, \mathrm{p}<0.02)$ and positively correlated

377 with soil loss on ignition (Pearson correlation $0.781, \mathrm{p}<0.05$ ), with soil $\mathrm{pH}$ and loss on ignition also

378 significantly negatively correlated (Pearson correlation $-0.78, p<0.05$ ). When the highest dose rate

379 site was removed from the data-set, there was no longer a significant correlation with either soil

$380 \mathrm{pH}$ or loss on ignition $(\mathrm{p}>0.05)$ indicating the importance of the low $\mathrm{pH}$ and high loss on ignition

381 values for the $\mathrm{H} 1$ Glubokya Marsh site in driving the significant relationships seen between the 382 soil properties.

Genetic and epigenetic characterisation of earthworms

385 Genetic structure within the collected earthworms was assessed using the AFLP analysis for 386 samples at the Mspl cleavage site for all sampled individuals. Two distinct groupings were 387 identified based on the obtained profiles. One group (orange squares in Supplementary Fig. 1) 388 comprised confirmed morphotype A. caliginosa. These individuals included earthworms collected 389 predominantly from two low exposure sites - C2: Zamozhnya and C3: Chernobyl gardens and a 390 single individual from medium exposure site M2: Forest Lake 2. Given the similarly low levels of 391 exposure experienced by all but one of the $A$. caliginosa, we focussed our further analysis on $O$. 392 lacteum for which individuals were available from a number of locations with different measured 393 and modeled exposure dose rates. Nonetheless, the $A$. caliginosa data was still valuable for 394 taxonomic assignment.

396 The remaining AFLP profiles (red circles and green triangles in Supplementary Fig. 1) comprise a 397 single and distinct group within the PCOA plot separated from the A. caliginosa samples along 398 PCoA1. This second set of profiles contains all individuals from morphotype O. lacteum for which 399 COI sequencing gave both a best BLAST hit against an existing $O$. lacteum $\mathrm{COI}$ sequence and 400 for which clustered with a known 0 . lacteum $\mathrm{COI}$ reference sequences (green triangle, 401 Supplementary Fig. 1) and also those morphotype O. lacteum from which the COI loci could not 402 be amplified and sequenced (red circles, Supplementary Fig. 1). Based on morphological similarity 403 of the individuals to the COI loci confirmed O. lacteum and the clustering of the AFLP profiles with 
404 those of the COI confirmed individuals in the PCoA plot, we conclude that all the amplified 405 individuals correspond to one or more clades of $O$. lacteum for which the used primer set does not 406 amplify the $\mathrm{COI}$ gene. As likely $\mathrm{O}$. lacteum, we concluded that these individuals can be analysed 407 alongside the $\mathrm{COI}$ confirmed $\mathrm{O}$. lacteum for the assessment of the genetic, epigenetic and 408 microbiome response to ionising radiation at CEZ sites. However, when assessing driver of 409 differences between profiles we used the two potential mitochondrial lineages as fixed factors 410 within ANOVAs of the PCoA scores.

412 The AFLP analysis based on Mspl cleavage site markers for all $O$. lacteum showed overlap of 413 profiles between replicate earthworms (Fig. 2). Analysis of PCoA 1 scores indicated a significant 414 site effect $(\mathrm{GLM} \mathrm{F}=7.95, \mathrm{p}<0.001)$, but not of $\mathrm{O}$. lacteum mitochondrial strain $(\mathrm{GLM}, \mathrm{F}=0.02$, $415 \mathrm{P}>0.01)$. Between site differences were found for earthworms from the $6.8 \mu \mathrm{Gy} / \mathrm{h}$ site and all other 416 locations, with the exception of the $0.12 \mu \mathrm{Gy} / \mathrm{h}$ site. The differences in AFLP profiles of earthworms 417 from intermediate dose rate sites compared to those from the higher and lower dose rate sites 418 suggests that exposure to ionising radiation is not the main driver of AFLP profile differences.

420 To assess DNA methylation patterns in sampled O. lacteum, a second AFLP analysis was 421 conducted using the methylation sensitive Hpall restriction enzyme. The meAFLP indicated an 422 average of $20.1 \%$ of methylation sensitive loci. DNA methylation levels showed no trend of hyper423 or hypo-methylation across sites (lowest average $16.7 \%$ at an exposure level of $0.12 \mu \mathrm{Gy} / \mathrm{h}$, 424 highest average $23.4 \%$ at an exposure level of $9.1 \mu \mathrm{Gy} / \mathrm{h}$, Fig. 3a). Principle coordinate analysis 425 of obtained methylation patterns indicated no site-specific structure among the profiles. Sampled 426 individuals showed no segregation within the PCoA on either of the first two principal coordinate 427 axes, which together account for only $20.6 \%$ of variance (Fig. 3b). No significant differences in 428 PCoA 1 or PCoA 2 scores were evident (PCoA 1 ANOVA F=2.09, $p>0.05 ; P C o A 2$ ANOVA F=1.08, $429 \mathrm{p}>0.05)$. Consistent methylation levels and the overlap of methylation patterns among earthworms 430 sampled from sites with different radiation dose rates, suggests no effects of radiation exposure 431 on global DNA methylation patterns at CEZ sites for O. lacteum. 
433 Sequencing of the 16S rRNA loci amplified from O. lacteum gut DNA identified 18870 OTUs at the $43497 \%$ similarity threshold. An NMDS analysis using data for sequences allocated to these OTUs 435 for each earthworm microbiome indicated a clear segregation of all individuals from each site 436 within an NMDS analysis plot (Fig. 4). NMDS1 and NMDS2 scores were significantly correlated 437 with median dose rate, soil $\mathrm{pH}$ and soil loss on ignition in all cases ( $\mathrm{p}<0.001$ all cases). However, 438 due to the small number of sites, such correlations with average dose rate may be a potential 439 artifact due to co-correlation effects. For this reason, to determine whether a given environmental 440 variable may be a driver of microbiome change, we assessed the structure or this relationship 441 notably the monotonic nature of the response (i.e. score increase or decrease progressively in 442 relation to environmental variable level). This site based separation by OTU profiles, did not show 443 a monotonic relationship with radiation exposure level along the NMDS 1 axis, with low exposure 444 level and high exposure levels sites having high NMDS 1 scores and medium exposure sites low 445 values (Supplementary Fig. 3A). There was also a non-monotonic relationship of NMDS 1 score 446 with site soil $\mathrm{pH}$, the highest axis values found for the sites with the most acidic and alkaline soils 447 (Supplementary Fig. 3B). There was an approximate monotonic relationship of NMDS 1 score 448 with site soil loss on ignition (Supplementary Fig. 3C), indicating that soil organic matter 449 composition may act as a critical driver of soil bacterial community structure either directly or 450 through indirect effects on other soil properties such as water holding capacity which may affect 451 soil responses to drought or frost. NMDS 2 score was close to monotonic related to calculated 452 dose rate (Supplementary Fig. 3D). However, as there is co-correlation of the environmental 453 drivers, both soil $\mathrm{pH}$ and loss on ignition also show a monotonic relationship with NMDS 2 score 454 (Supplementary Fig. 3E and 3F).

456 Diversity expressed as Fishers log alpha was highest in the bacterial gut microbiome samples in 457 O. lacteum earthworms from the two lowest exposure sites (C1 Glinka, C4 Marsh) and lowest in 458 the two highest exposure sites (H1 Glubokya Marsh, M2 Forest Lake). Diversity increased 459 systematically with increasing median earthworm dose rate (Fig. $5 \mathrm{~A}$ ). As pH is strongly co- 
460 correlated with earthworm dose rate, there is also a relationship of increasing diversity at high soil $461 \mathrm{pH}$ values. Diversity was not systematically related to soil loss on ignition, with high diversity at 462 both intermediate and high soil loss on ignition sites (Fig. 5B).

463 


\section{Discussion}

465 The scale and devastating nature of the Chernobyl accident has created a legacy of exposure for wildlife living around the site of the former power plant. Radioecologists have studied the long-

467 term effects of the resulting exposure, both to support local management and to better understand 468 any long-term effects on individuals, populations, and ecosystems. Comprehensive reviews of the 469 phenotypic effects observed in wildlife experiencing prolonged exposure to elevated radionuclide 470 levels in the CEZ have highlighted the range of studies on the structure and function of exposure 471 populations and communities from soil microbial communities to charismatic vertebrate wildlife 472 (e.g. Beresford et al., 2016; Geras'kin et al., 2008; Hinton et al., 2007; Lourenco et al., 2016; 473 Steinhauser et al., 2014). Within the range of published studies, there is a lack of consensus on 474 the long-term effects of chronic radiation exposure for wildlife in the CEZ (Beresford et al., 2019b).

475 The impacts of radiation exposure on the hologenome and subsequent impacts on exposure and 476 subsequent generations have been identified as one factor that may contribute to the impacts of 477 long-term exposure in the CEZ (Horemans et al., 2019). Understanding such effects may benefit 478 from addressing uncertainties relating to the chronic effects of radiation exposure.

480 The prolonged exposure of soil invertebrates to long-lived contaminants has been shown to 481 change population genetic and epigenetic traits that underpin the development of tolerance 482 (Horemans et al., 2019). The relatively high reproductive rate of many invertebrates enables rare 483 or novel gene variants associated with adaptive traits to spread relatively quickly throughout 484 populations under selection pressure. Many invertebrates have been shown to develop adaptation 485 to contaminants (Klerks \& Weis 1987; Posthuma \& Van Straalen 1993). For earthworms, tolerance 486 to metal exposure has been shown in populations inhabiting sites polluted with a number of 487 different metals. Andre et al. (2010) used genetic marker analysis to identify an 'ecological island' 488 with little genetic overlap in L. rubellus populations inhabiting lead polluted and clean soils under 489 different $\mathrm{pH}$ conditions. Mutations in the Ca-transport gene SERCA were found between 490 populations, identifying this locus as a possible mechanism for adaptation. Langdon et al. (1999) 491 also working with $L$. rubellus found that individuals inhabiting two mining areas heavily polluted 
492 with arsenic and copper (Devon Great Consols, Carrock Fell) could survive in arsenic-spiked soil 493 that was acutely toxic to earthworms from an uncontaminated location. This tolerance was 494 preserved following culturing over two generations, suggesting a genetic basis for the adapted 495 phenotype (Langdon et al., 2009). Kille et al. (2013) used mitochondrial (COI) marker analysis and 496 meAFLP to assess the genetic and epigenetic traits of $L$. rubellus from the same Devon Great 497 Consols mine site studied by Langdon et al. (2009). Both the COI analysis and AFLP markers 498 identified two genetic lineages of $L$. rubellus at the mine site consistent with previous findings 499 (Anderson et al., 2017; Giska et al., 2015; Spurgeon et al., 2016). For the most genetically diverse 500 lineage (A), segregation of local collection site populations by AFLP profiles was seen. For the 501 second, less diverse, lineage (B), this genetic segregation by AFLP profile was not seen, however,

502 site segregation by meAFLP profiles was observed. This indicates a contribution of the epigenome 503 to the observed adaptive phenotype in Lineage B L. rubellus. This unique finding indicates the 504 need to assess how both genetic sequence changes and DNA methylation can play a role in the 505 development of adaptive phenotypes in earthworms.

507 An initial survey of Chernobyl earthworm communities identified that species are patchily 508 distributed across the exclusion zone. The dominant soil type in the region is sandy in nature with 509 characteristically low pH and organic matter content. Such free draining acid soils have been found 510 to be poorly suited for earthworms, which maintain larger and more diverse communities in areas 511 with high clay or silt content, high water holding capacity and high electrical conductivity (Nuutinen 512 et al., 1998; Valckx et al., 2009). The main locations from which earthworms were collected were 513 associated either with water bodies (lake or river margins, marshland) or improved soils managed 514 as domestic gardens in areas of past human habitation. This indicates that soil hydrological status 515 acts as a major driver of earthworm distributions within the CEZ.

517 Two species of earthworms were found in sufficient numbers to provide potential samples for 518 analysis. Both $O$. lacteum and $A$. caliginosa are endogeic species that live in the mineral soil 519 layers. Exposure in this habitat would be lower than to epigeic species living in the top-soil, since 
520 almost 20 years after the accident, radionuclides remain largely in the upper $0-20 \mathrm{~cm}$ soil layers

521 (Almgren and Isaksson, 2006; Ivanov and Kashparov, 2003). However, at the soil sampling depth

522 used $(10 \mathrm{~cm})$, calculated dose rates would be generally representative for species living within the

523 mineral soil layer. The individual measurements of relevant external and internal radionuclide

524 concentrations for dosimetry assessment confirmed this exposure. Among the earthworms

525 species found during the preliminary survey and main field sampling campaign, only 0 . lacteum

526 was found in sufficient number across CEZ sites with comparatively low, medium and high

527 exposure. O. lacteum is an endogeic earthworms species that is able to undertake both sexual

528 and parthenogenetic reproduction, which may be relevant both for its relative prevalence in the

529 CEZ and also potentially for its adaptation to local environmental conditions. A. caliginosa, another

530 albeit larger endogeic earthworm species, was in contrast collected only from sites with near

531 background levels. Too few sites were sampled to attribute the absence of $A$. caliginosa to the

532 prevailing exposure levels. Absence is likely to be explained simply by the lack of suitable habitat

533 for this species at the more contaminated sites.

535 Our analysis of the 0 . lacteum hologenome included measurement of genetic, epigenetic and 536 microbiome characteristics. However, while covering key aspects, not all hologenome traits were

537 included. For example in assessing epigenome responses, we focussed on an established method

538 to measure coarse DNA methylation coverage. These DNA methylation marks were not mapped

539 to genomic locations to provide insights in their functional role in gene regulation. Further, other

540 potential epigenetic changes linked to the modification of histone protein and expression of

541 regulatory microRNAs were not measured. These epigenome components have previously been

542 found to be active in earthworms (Gong et al., 2010; Novo et al., 2015). Hence, their future

543 inclusion within a more complete assessment of hologenome responses to ionising radiation

544 exposures may be warranted.

546 The genetic analysis of $O$. lacteum using AFLP markers at Mspl restriction sites indicated that all 547 morphotype earthworm from this species exist as a single group. Using the COI primers, 
sequences from $53 \%$ of all collected morphotype 0 . lacteum failed to amplify despite best efforts.

549 The reasons for this failure are currently not clear, but may be related to the presence of specific 550 point sequence variations in the primer binding region of the COI sequence in these individuals.

551 The presence of these polymorphisms may be indicative of the cryptic mitochondrial lineages in

552 this species, as has been found for O. lacteum (Klarica et al., 2012) and also commonly for other 553 earthworm including L. rubellus (Anderson et al., 2017; Andre et al., 2010), Eisenia fetida 554 (PerezLosada et al., 2009) and Allolobophora chlorotica (King et al., 2008). The more comprehensive AFLP data, however, refutes the presence of cryptic $O$. lacteum species, as the PCoA analysis of the AFLP data shows that CEZ O. lacteum comprise a single clade.

Site-specific structure was observed within the Mspl restriction site AFLP analysis. This was not, 559 however, correlated with modeled earthworm dose rate. This suggests that there has been no 560 selection relating to the ionising radiation exposure. Similarly, we found no difference in DNA 561 methylation levels or structure within the meAFLP analysis, indicating that there is no site, and 562 hence ionising radiation exposure level, influence on the distribution of DNA methylation within the 563 O. lacteum genome. Many contaminants have been shown to alter gene methylation patterns in 564 invertebrates (Santoyo et al., 2011) and plants (Chinnusamy and Zhu, 2009). In response to 565 ionising radiation exposure in the CEZ, hypermethylation of DNA has been observed in pine trees 566 (Pinus sp.) and Arabidopsis thaliana (Kovalchuk et al., 2004; Kovalchuk et al., 2003) and it has 567 been suggested that individuals of adult pale blue grass butterfly Zizeeria maha at Fukahima have 568 shown inherited abnormalities from the F1 to the F2 generation (Hiyama et al., 2012). Epigenetic 569 mechanisms were proposed to play a role in both cases. Absence of a clear indication of changes 570 in patterns of DNA methylation measured using meAFLP for $O$. lacteum may indicate that adaptive 571 phenotypes may be regulated through other epigenome components. Alternatively, it is possible 572 that exposure at the sampled CEZ sites is not sufficient to cause significant epigenetic changes in 573 this species. However, in this context, it is important also to consider that meAFPL provides only 574 a very course assessment of one aspect of the response to the epigenome to perturbations. Other 575 methods for quantifying DNA methylation targeting either speciifc genes through methylation- 
specific PCR or genome wide methylation analysis using high throughput sequencing approaches

577 may better resolve any specific DNA methylation changes resulting from radiation exposure.

578 Further, there are other epigenetic mechanisms that may also play a role.

580 The analysis of the structure of the CEZ $O$. lacteum microbiome indicated clear site structure in 581 the composition of gut bacteria as analysed using 16S RNA gene loci amplification and 582 sequencing. The earthworm microbiome has previously been found to be shifted in response to 583 the presence of arsenic in contaminated soils at a mine site (Pass et al., 2015). In this study, the 584 earthworm-associated microbiome was found to differ from the surrounding environment. Several 585 taxa observed in uncontaminated control microbiomes were found to be suppressed by

$586 \mathrm{metal} / \mathrm{metalloid}$ field exposure, including the eradication of the hereto ubiquitously associated 587 Verminephrobacter symbiont, which raises implications to its functional role in the earthworm 588 microbiome (Pass et al., 2015).

590 It has been shown that the earthworm gut bacterial microbiome is a combination of soil associated 591 species passing through the gut and also a range of strongly host related core species present 592 across different soils (Liu et al., 2018; Pass et al., 2015). As the earthworms sampled in this survey 593 were not starved or washed to remove soil in the gut, both core 0 . lacteum and also soil associated 594 species would be present. Microbiome structure and diversity was systematically related to site 595 soil properties. Analyses through 16s rRNA sequencing have indicated that soil properties can 596 significantly affect the bacterial community (George et al., 2019; Plassart et al., 2019). Griffiths et 597 al. (2011) showed that $\mathrm{pH}$ was a dominant driver of national patterns of soil bacterial species 598 distribution, with other environmental variables and climatic variables and spatial correlations at 599 local scale also influencing community structure. Given that the soil bacterial community 600 contributes a significant proportion of earthworm microbiome species, the potential exists for soil 601 properties to be responsible for differences in the microbiome. 
603 O. lacteum gut bacterial microbiome structure was site specific and was weakly correlated with

604 dose rate. However, across sites there was also co-correlation between earthworm dose rates

605 and other soil properties, notably $\mathrm{pH}$. Subtle shifts in soil bacterial community structure have 606 previously been shown to respond to radiation exposure, although at much higher dose rates than 607 those quantified here (Jones et al., 2004; McNamara et al., 2007; Niedree et al., 2013). Hence, 608 changes in earthworm gut microbiome structure and diversity may be related to soil dose rates. 609 However, the widely known role of soil pH as a driver of bacterial community structural difference 610 makes the attribution of the observed difference in microbiome structure to radiation exposure 611 challenging. Further, soil $\mathrm{pH}$ has been shown to be a key determinant of the speciation of metals 612 and radionuclides in soil (Lofts and Tipping, 2011; Vandenhove et al., 2007), with resulting effects 613 on bioavailability (Hegazy et al., 2013; Spurgeon et al., 2006). Hence, as well as the potential 614 direct effects of radionuclide and $\mathrm{pH}$, there may be interactive $\mathrm{pH}$ effects on radionuclide 615 bioavailability which may complicate the attribution of $O$. lacteum gut bacterial community variation 616 to any single driver.

\section{Conclusions}

619 Prevailing habitat, soil and climatic conditions mean that the distribution of earthworms in the CEZ 620 is spatially limited. Our survey suggests that earthworms are restricted to sites associated with 621 water bodies and in abandoned urban gardens. Our hologenome analyses indicate that there is 622 no major impact of the prolonged exposure of earthworms to radionuclides on the measured 623 genetic or epigenetic characteristics of earthworms collected across our studied sites. Earthworm 624 gut bacterial microbiome community did show strong site specific structure that could be related 625 to the prevailing dose rate predicted for earthworms living at each site. Co-correlation of other soil 626 properties with dose rate and potential interactions, however, means that it is not possible to 627 attribution of these changes specifically to radionuclide exposure. A wider survey is needed to 628 more robustly address questions relating to the impacts of radionuclide exposure on the 629 microbiome. Due to their limited distribution in the CEZ earthworm may not be the best study group 630 for such an extended survey. Robust wide-scale microbiome community structure is a potentially 
631 effective approach, although it is acknowledged that microbe may be among some of the most 632 radio insensitive groups of organisms, the interplay between host health and microbiome structure 633 may indicate a wider interaction at the level of the hologenome. 


\section{Acknowledgments}

635 This work was supported by the EU H2020 COMET (Coordination and implementation of a pan-

636 European instrument for radioecology) research project (grant number: Fission-2012-3.4.1-

637 604794), by NERC National Capability funding to the Centre for Ecology and Hydrology under the

638 Institutional fund IMP scheme for D. Spurgeon, and the Norwegian Research Council CERAD

639 project (grant number: 223268/F50). Greg Lamarre from the Czech Academy of Sciences was a

640 part of the expedition team and contributed to the field collection.

641

642 
Almgren, S., Isaksson, M., 2006. Vertical migration studies of Cs-137 from nuclear weapons

648 Anderson, C., Cunha, L., Sechi, P., Kille, P., Spurgeon, D., 2017. Genetic variation in populations 649 of the earthworm, Lumbricus rubellus, across contaminated mine sites. Bmc Genetics 18, 97.

651 Andre, J., King, R.A., Stürzenbaum, S.R., Kille, P., Hodson, M.E., Morgan, A.J., 2010. Molecular 652 genetic differentiation in earthworms inhabiting a heterogeneous $\mathrm{Pb}$-polluted landscape. 653 Environmental Pollution 158, 883-890.

Beresford, N.A., Barnett, C.L., Gashschak, S., Maksimenko, A., Guliaichenko, E., Wood, M.D., Exclusion Zone and resultant radiation exposures. Journal of Environmental Radioactivity, 105661. https://doi.org/105610.101016/j.jenvrad.102018.105602.105007.

660 Beresford, N.A., Fesenko, S., Konoplev, A., Skuterud, L., Smith, J.T., Voigt, G., 2016. Thirty years 661 after the Chernobyl accident: What lessons have we learnt? Journal of Environmental Radioactivity $662157,77-89$.

664 Beresford, N.A., Scott, E.M., Copplestone, D., 2019b. Field effects studies in the Chernobyl 665 Exclusion Zone: Lessons to be learnt. Journal of Environmental Radioactivity, 1055893.

667 Bonzom, J.M., Hattenschwiler, S., Lecomte-Pradines, C., Chauvet, E., Gaschak, S., Beaugelin668 Seiller, K., Della-Vedova, C., Dubourg, N., Maksimenko, A., Garnier-Laplace, J., Adam- 
669 Guillermin, C., 2016. Effects of radionuclide contamination on leaf litter decomposition in the

670 Chernobyl exclusion zone. Science of the Total Environment 562, 596-603.

672 Bordenstein, S.R., Theis, K.R., 2015. Host biology in light of the microbiome: Ten principles of 673 holobionts and hologenomes. PLOS Biology 13.

Boubriak, II, Grodzinsky, D.M., Polischuk, V.P., Naumenko, V.D., Gushcha, N.P., Micheev, A.N., McCready, S.J., Osborne, D.J., 2008. Adaptation and impairment of DNA repair function in pollen of Betula verrucosa and seeds of Oenothera biennis from differently radionuclide-contaminated sites of Chernobyl. Annals of Botany 101, 267-276.

Brown, J.E., Alfonso, B., Avila, R., Beresford, N.A., Copplestone, D., Prohl, G., Ulanovsky, A., 681 2008. The ERICA Tool. Journal of Environmental Radioactivity 99, 1371-1383.

682

683 Chinnusamy, V., Zhu, J.K., 2009. Epigenetic regulation of stress responses in plants. Current 684 Opinion in Plant Biology 12, 133-139.

685

686 Darriba, D., Taboada, G.L., Doallo, R., Posada, D., 2012. jModelTest 2: more models, new 687 heuristics and parallel computing. Nature Methods 9, 772-772.

689 DeSantis, T.Z., Hugenholtz, P., Larsen, N., Rojas, M., Brodie, E.L., Keller, K., Huber, T., Dalevi, 690 D., Hu, P., Andersen, G.L., 2006. Greengenes, a chimera-checked 16S rRNA gene database and 691 workbench compatible with ARB. Applied and Environmental Microbiology 72, 5069-5072.

693 Dubois, C., Pophillat, M., Audebert, S., Fourquet, P., Lecomte, C., Dubourg, N., Galas, S., Camoin, 694 L., Frelon, S., 2019. Differential modification of the C. elegans proteome in response to acute and 
695

696

697

698

699

700

701

702

703

704

705

706

707

708 Folmer, O., Black, M., Hoeh, W., Lutz, R., Vrijenhoek, R., 1994. DNA primers for amplification

709 of mitochondrial cytochrome c oxidase subunit I from diverse metazoan invertebrates. Molecular

710 Marine Biology and Biotechnology 3, 294-299.

711

712 George, P.B.L., Lallias, D., Creer, S., Seaton, F.M., Kenny, J.G., Eccles, R.M., Griffiths, R.I.,

713 Lebron, I., Emmett, B.A., Robinson, D.A., Jones, D.L., 2019. Divergent national-scale trends of

714 microbial and animal biodiversity revealed across diverse temperate soil ecosystems. Nature

715 Communications 10, 11.

716

717 Geras'kin, S.A., Fesenko, S.V., Alexakhin, R.M., 2008. Effects of non-human species irradiation 718 after the Chernobyl NPP accident. Environment International 34, 880-897. 
720 Giska, I., Sechi, P., Babik, W., 2015. Deeply divergent sympatric mitochondrial lineages of the 721 earthworm Lumbricus rubellus are not reproductively isolated. BMC Evolutionary Biology 15, 722217.

724 Gong, P., Xie, F.L., Zhang, B.H., Perkins, E.J., 2010. In silico identification of conserved 725 microRNAs and their target transcripts from expressed sequence tags of three earthworm species. 726 Computational Biology and Chemistry 34, 313-319.

728 Griffiths, R.I., Thomson, B.C., James, P., Bell, T., Bailey, M., Whiteley, A.S., 2011. The bacterial 729 biogeography of British soils. Environmental Microbiology 13, 1642-1654.

731 Hegazy, A.K., Afifi, S.Y., Alatar, A.A., Alwathnani, H.A., Emam, M.H., 2013. Soil characteristics 732 influence the radionuclide uptake of different plant species. Chemistry and Ecology 29, 255-269.

734 Hertel-Aas, T., Oughton, D.H., Jaworska, A., Bjerke, H., Salbu, B., Brunborg, G., 2007. Effects of 735 chronic gamma irradiation on reproduction in the earthworm Eisenia fetida (Oligochaeta). 736 Radiation Research 168, 515-526.

738 Hinton, T.G., Alexakhin, R., Balonov, M., Gentner, N., Hendry, J., Prister, B., Strand, P., 739 Woodhead, D., 2007. Radiation-induced effects on plants and animals: Findings of the united 740 nations Chernobyl forum. Health Physics 93, 427-440.

742 Hiyama, A., Nohara, C., Kinjo, S., Taira, W., Gima, S., Tanahara, A., Otaki, J.M., 2012. The 743 biological impacts of the Fukushima nuclear accident on the pale grass blue butterfly. Scientific 744 Reports 2, 570. 
746 Horemans, N., Spurgeon, D.J., Lecomte-Pradines, C., Saenen, E., Bradshaw, C., Oughton, D.,

747 Rasnaca, I., Kamstra, J.H., Adam-Guillermin, C., 2019. Current evidence for a role of epigenetic 748 mechanisms in response to ionizing radiation in an ecotoxicological context. Environmental 749 Pollution 251, 469-483.

751 Ivanov, Y.A., Kashparov, V.A., 2003. Long-term dynamics of the radioecological situation in 752 terrestrial ecosystems of the Chernobyl exclusion zone. Environmental Science and Pollution 753 Research, 13-20.

Jones, H.E., West, H.M., Chamberlain, P.M., Parekh, N.R., Beresford, N.A., Crout, N.M.J., 2004.

Effects of gamma irradiation on Holcus lanatus (Yorkshire fog grass) and associated soil microorganisms. Journal of Environmental Radioactivity 74, 57-71.

759 Kille, P., Andre, J., Anderson, C., Ang, H.N., Bruford, M.W., Bundy, J.G., Donnelly, R., Hodson,

760 M.E., Juma, G., Lahive, E., Morgan, A.J., Sturzenbaum, S.R., Spurgeon, D.J., 2013. DNA sequence 761 variation and methylation in an arsenic tolerant earthworm population. Soil Biology \& 762 Biochemistry 57, 524-532.

764 King, R.A., Tibble, A.L., Symondson, W.O.C., 2008. Opening a can of worms: unprecedented 765 sympatric cryptic diversity within British lumbricid earthworms. Molecular Ecology 17, 46847664698.

Klarica, J., Kloss-Brandstatter, A., Traugott, M., Juen, A., 2012. Comparing four mitochondrial 769 genes in earthworms - Implications for identification, phylogenetics, and discovery of cryptic species. Soil Biology \& Biochemistry 45, 23-30. 
772 Kovalchuk, I., Abramov, V., Pogribny, I., Kovalchuk, O., 2004. Molecular aspects of plant 773 adaptation to life in the Chernobyl zone. Plant Physiology 135, 357-363.

775 Kovalchuk, O., Burke, P., Arkhipov, A., Kuchma, N., James, S.J., Kovalchuk, I., Pogribny, I., 776 2003. Genome hypermethylation in Pinus silvestris of Chernobyl - a mechanism for radiation 777 adaptation? Mutation Research-Fundamental and Molecular Mechanisms of Mutagenesis 529, 1377820.

780 Kozich, J.J., Westcott, S.L., Baxter, N.T., Highlander, S.K., Schloss, P.D., 2013. Development of 781 a dual-index sequencing strategy and curation pipeline for analyzing amplicon sequence data on 782 the MiSeq Illumina sequencing platform. Applied and Environmental Microbiology 79, 51127835120.

785 Krivolutsky, D.A., 1996. Soil fauna as bioindicator of radioactive pollution, in: vanStraalen, N.M., 786 Krivolutsky, D.A. (Eds.). NATO Science Series Partnership Sub-series 2, Environmental Security pp. 189-196.

789 Krivolutzkii, D.A., Pokarzhevskii, A.D., Viktorov, A.G., 1992. Earthworm populations in soils 790 contaminated by the Chernobyl Atomic Power-station accident, 1986-1988. Soil Biology \& 791 Biochemistry 24, 1729-1731.

793 Langdon, C.J., Morgan, A.J., Charnock, J.M., Semple, K.T., Lowe, C.N., 2009. As-resistance in 794 laboratory-reared F1, F2 and F3 generation offspring of the earthworm Lumbricus rubellus 795 inhabiting an As-contaminated mine soil. Environmental Pollution 157, 3114-3119. 
797 Langdon, C.J., Piearce, T.G., Black, S., Semple, K.T., 1999. Resistance to arsenic-toxicity in a 798 population of the earthworm Lumbricus rubellus. Soil Biology \& Biochemistry 31, 1963-1967.

800 Langdon, C.J., Piearce, T.G., Meharg, A.A., Semple, K.T., 2003. Inherited resistance to arsenate 801 toxicity in two populations of Lumbricus rubellus. Environmental Toxicology and Chemistry 22, $802 \quad 2344-2348$.

803

804 Lecomte-Pradines, C., Hertel-Aas, T., Coutris, C., Gilbin, R., Oughton, D., Alonzo, F., 2017. A 805 dynamic energy-based model to analyze sublethal effects of chronic gamma irradiation in the 806 nematode Caenorhabditis elegans. Journal of Toxicology and Environmental Health A 80, 830807844.

808

809 Liu, D.F., Lian, B., Wu, C.H., Guo, P.J., 2018. A comparative study of gut microbiota profiles of 810 earthworms fed in three different substrates. Symbiosis 74, 21-29.

812 Lofts, S., Tipping, E., 2011. Assessing WHAM/Model VII against field measurements of free metal 813 ion concentrations: model performance and the role of uncertainty in parameters and inputs. 814 Environmental Chemistry 8, 501-516.

816 Lourenco, J., Mendo, S., Pereira, R., 2016. Radioactively contaminated areas: Bioindicator species 817 and biomarkers of effect in an early warning scheme for a preliminary risk assessment. Journal of 818 Hazardous Materials 317, 503-542.

820 Marinissen, J.C.Y., Vandenbosch, F., 1992. Colonization of new habitats by earthworms. 821 Oecologia 91, 371-376. 
823 McMurdie, P.J., Holmes, S., 2013. Phyloseq: An R package for reproducible interactive analysis 824 and graphics of microbiome census data. PLOS One 8.

826 McNamara, N.P., Griffiths, R.I., Tabouret, A., Beresford, N.A., Bailey, M.J., Whiteley, A.S., 2007.

827 The sensitivity of a forest soil microbial community to acute gamma-irradiation. Applied Soil 828 Ecology 37, 1-9.

830 Moller, A.P., Mousseau, T.A., 2009. Reduced abundance of insects and spiders linked to radiation 831 at Chernobyl 20 years after the accident. Biology Letters 5, 356-359.

833 Nakamori, T., Yoshida, S., Kubota, Y., Ban-nai, T., Kaneko, N., Hasegawa, M., Itoh, R., 2008. 834 Effects of acute gamma irradiation on Folsomia candida (Collembola) in a standard test. 835 Ecotoxicology and Environmental Safety 71, 590-596.

837 Niedree, B., Berns, A.E., Vereecken, H., Burauel, P., 2013. Do Chernobyl-like contaminations with 838 Cs-137 and Sr-90 affect the microbial community, the fungal biomass and the composition of soil 839 organic matter in soil? Journal of Environmental Radioactivity 118, 21-29.

841 Novo, M., Lahive, E., Diez-Ortiz, M., Matzke, M., Morgan, A.J., Spurgeon, D.J., Svendsen, C., 842 Kille, P., 2015. Different routes, same pathways: Molecular mechanisms under silver ion and 843 nanoparticle exposures in the soil sentinel Eisenia fetida. Environmental Pollution 205, 385-393.

845 Nuutinen, V., Pitkanen, J., Kuusela, E., Widbom, T., Lohilahti, H., 1998. Spatial variation of an 846 earthworm community related to soil properties and yield in a grass-clover field. Applied Soil 847 Ecology 8, 85-94. 
849 Ouellet, G., Lapen, D.R., Topp, E., Sawada, M., Edwards, M., 2008. A heuristic model to predict

850 earthworm biomass in agroecosystems based on selected management and soil properties. Applied 851 Soil Ecology 39, 35-45.

853 Pass, D.A., Morgan, A.J., Read, D.S., Field, D., Weightman, A.J., Kille, P., 2015. The effect of 854 anthropogenic arsenic contamination on the earthworm microbiome. Environmental Microbiology $85517,1884-1896$.

857 PerezLosada, M., Ricoy, M., Marshall, J.C., Dominguez, J., 2009. Phylogenetic assessment of the earthworm Aporrectodea caliginosa species complex (Oligochaeta: Lumbricidae) based on mitochondrial and nuclear DNA sequences. Molecular Phylogenetics and Evolution 52, 293-302.

861 Plassart, P., Prevost-Boure, N.C., Uroz, S., Dequiedt, S., Stone, D., Creamer, R., Griffiths, R.I., 862 Bailey, M.J., Ranjard, L., Lemanceau, P., 2019. Soil parameters, land use, and geographical 863 distance drive soil bacterial communities along a European transect. Scientific Reports 9.

865 Popic, J.M., Salbu, B., Skipperud, L., 2012. Ecological transfer of radionuclides and metals to free866 living earthworm species in natural habitats rich in NORM. Science of the Total Environment 414, $867 \quad 167-176$.

869 Posada, D., 2008. jModelTest: Phylogenetic model averaging. Molecular Biology and Evolution $870 \quad 25,1253-1256$.

872 Rognes, T., Flouri, T., Nichols, B., Quince, C., Mahe, F., 2016. VSEARCH: a versatile open source 873 tool for metagenomics. Peerj 4. 
875 Rusin, A., Lapied, E., Le, M., Seymour, C., Oughton, D., Haanes, H., Mothersill, C., 2019. Effect

876 of gamma radiation on the production of bystander signals from three earthworm species irradiated 877 in vivo. Environmental Research 168, 211-221.

879 Santoyo, M.M., Flores, C.R., Torres, A.L., Wrobel, K., Wrobel, K., 2011. Global DNA methylation 880 in earthworms: A candidate biomarker of epigenetic risks related to the presence of 881 metals/metalloids in terrestrial environments. Environmental Pollution 159, 2387-2392.

883 Sowmithra, K., Shetty, N.J., Harini, B.P., Jha, S.K., Chaubey, R.C., 2015. Effects of acute gamma 884 radiation on the reproductive ability of the earthworm Eisenia fetida. Journal of Environmental 885 Radioactivity 140, 11-15.

886

887 Spurgeon, D.J., Liebeke, M., Anderson, C., Kille, P., Lawlor, A., Bundy, J.G., Lahive, E., 2016. 888 Ecological drivers influence the distributions of two cryptic lineages in an earthworm 889 morphospecies. Applied Soil Ecology 108, 8-15.

891 Spurgeon, D.J., Lofts, S., Hankard, P.K., Toal, M., McLellan, D., Fishwick, S., Svendsen, C., 2006. 892 Effect of $\mathrm{pH}$ on metal speciation and resulting metal uptake and toxicity for earthworms. 893 Environmental Toxicology and Chemistry 25, 788-796.

895 Srut, M., Drechsel, V., Hockner, M., 2017. Low levels of Cd induce persisting epigenetic 896 modifications and acclimation mechanisms in the earthworm Lumbricus terrestris. PLOS One 12.

898 Steinhauser, G., Brandl, A., Johnson, T.E., 2014. Comparison of the Chernobyl and Fukushima 899 nuclear accidents: A review of the environmental impacts. Science of the Total Environment 470, $900 \quad 800-817$. 
902 Tindall, B.J., Rossello-Mora, R., Busse, H.J., Ludwig, W., Kampfer, P., 2010. Notes on the 903 characterization of prokaryote strains for taxonomic purposes. International Journal of Systematic 904 and Evolutionary Microbiology 60, 249-266.

905

906 Uematsu, S., Smolders, E., Sweeck, L., Wannijn, J., Van Hees, M., Vandenhove, H., 2015. 907 Predicting radiocaesium sorption characteristics with soil chemical properties for Japanese soils. 908 Science of the Total Environment 524, 148-156.

909

910 Valckx, J., Cockx, L., Wauters, J., VanMeirvenne, M., Govers, G., Hermy, M., Muys, B., 2009.

911 Within-field spatial distribution of earthworm populations related to species interactions and soil 912 apparent electrical conductivity. Applied Soil Ecology 41, 315-328.

914 Vandenhove, H., Van Hees, M., Wouters, K., Wannijn, J., 2007. Can we predict uranium 915 bioavailability based on soil parameters? Part 1: Effect of soil parameters on soil solution uranium 916 concentration. Environmental Pollution 145, 587-595.

918 Wang, Q., Garrity, G.M., Tiedje, J.M., Cole, J.R., 2007. Naive Bayesian classifier for rapid 919 assignment of rRNA sequences into the new bacterial taxonomy. Applied and Environmental 920 Microbiology 73, 5261-5267.

922 Xiong, L.Z., Xu, C.G., Maroof, M.A.S., Zhang, Q.F., 1999. Patterns of cytosine methylation in an 923 elite rice hybrid and its parental lines, detected by a methylation-sensitive amplification 924 polymorphism technique. Molecular \& General Genetics 261, 439-446. 
926 Zaitsev, A.S., Gongalsky, K.B., Nakamori, T., Kaneko, N., 2014. Ionizing radiation effects on soil 927 biota: Application of lessons learned from Chernobyl accident for radioecological monitoring. 928 Pedobiologia 57, 5-14. 
931 biological replicates from each collection location

932

\begin{tabular}{|c|c|c|c|c|c|c|c|c|}
\hline Site Number & Northing & Easting & $\begin{array}{l}\text { Distance to } \\
\text { Power Plant } \\
(\mathbf{k m})\end{array}$ & Habitat & Sample date & $\begin{array}{l}\text { Species } \\
\text { present }\end{array}$ & $\begin{array}{c}\text { Aporrectdea } \\
\text { caliginosa }\end{array}$ & $\begin{array}{c}\text { Octolasion } \\
\text { lacteum }\end{array}$ \\
\hline C1 Glinka (4) & 51.241295 & 29.9908887 & 18.3 & Wetland margin & 06/10/2016 & 5 & 0 & 3 \\
\hline C2 Zamozhnya (7) & 51.236371 & 29.898201 & 20.7 & Wetland margin & 07/10/2016 & 4 & 13 & 0 \\
\hline C3 Chernobyl Garden (6) & 51.279219 & 30.213228 & 14.5 & Abandoned Garden & 07/10/2016 & 3 & 18 & 0 \\
\hline C4 Marsh (9) & 51.474772 & 29.633966 & 33.5 & Marshland & $10 / 10 / 2016$ & 2 & 0 & 11 \\
\hline M1 Forest lake 1 (2) & 51.41190 & 30.100092 & 2.6 & Wetland margin & 06/10/2016 & 2 & 0 & 27 \\
\hline M2 Forest lake 2 (3) & 51.410225 & 30.100816 & 2.2 & Wetland margin & 06/10/2016 & 3 & 1 & 16 \\
\hline H1 Glubokya Marsh) (8) & 51.445025 & 30.063611 & 6.5 & Marshland & 08/10/2016 & 2 & 0 & 13 \\
\hline
\end{tabular}


Table 2. Site soil properties, measured radionuclide concentrations, modeled total earthworm and gut dose rates and median dose rate values (used for site labels) for all collection locations.

\begin{tabular}{|c|c|c|c|c|c|c|c|c|c|c|}
\hline Site Number & Soil pH & $\begin{array}{c}\text { Soil loss } \\
\text { on ignition } \\
(\%)\end{array}$ & $\begin{array}{c}\text { Measured } \\
\text { surface dose rate } \\
(\mu \mathrm{G} / \mathrm{h})\end{array}$ & $\begin{array}{c}\text { Soil Bq/g } \\
{ }^{137} \mathrm{CS}\end{array}$ & $\begin{array}{c}\text { Soil Bq/g } \\
{ }^{90} \mathrm{Sr}\end{array}$ & $\begin{array}{c}\text { Soil Bq/g } \\
{ }^{241} \mathrm{Am}\end{array}$ & $\begin{array}{c}\text { Soil } \mathrm{Bq} / \mathrm{g} \\
{ }_{\text {total }}^{\mathrm{Pu}}\end{array}$ & $\begin{array}{c}\text { Earthworm } \\
\text { dose rate } \\
\text { range }(\mu \mathrm{Gy} / \mathrm{h})\end{array}$ & $\begin{array}{c}\text { Worm gut } \\
\text { activty Bq/g } \\
{ }^{137} \mathrm{Cs}\end{array}$ & $\begin{array}{c}\text { Median worm } \\
\text { dose rate for } \\
\text { site }(\mu \mathrm{Gy} / \mathrm{h})\end{array}$ \\
\hline C1 Glinka (4) & 6.23 & 4.8 & $0.05-0.11$ & 0.3 & $<0.48$ & 0.003 & $<0.02$ & $0.096-0.144$ & $<2$ & 0.12 \\
\hline C2 Zamozhnya (7) & 5.87 & 8.5 & 0.1 & 0.2 & $<0.48$ & 0.004 & $<0.02$ & $0.072-0.108$ & $<2$ & 0.09 \\
\hline C3 Chernobyl Garden (6) & 6.66 & 5.1 & 0.2 & 0.66 & $<0.48$ & 0.02 & $<0.02$ & $0.27-0.41$ & $<2$ & 0.34 \\
\hline C4 Marsh (9) & 5.78 & 10.3 & $0.15-0.2$ & 0.54 & $<0.48$ & 0.01 & $<0.02$ & $0.19-0.29$ & $2.2+/-0.9$ & 0.24 \\
\hline H1 Glubokya Marsh (8) & 4.67 & 15.6 & $8-12$ & $49-86$ & $18-28$ & $2.3-4.1$ & $0.6-2.3$ & $29-53$ & $20-76$ & 45 \\
\hline
\end{tabular}




\section{Legends to figures}

Figure 1. Relative proportionate contribution of different measured radionuclides at sites with median ambient dose rates of 0.24 (Left pie chart) and $45 \mu \mathrm{Gy} / \mathrm{h}$ (Right pie chart B) for earthworms sampled in the CEZ.

Figure 2. Principle coordinate analysis of $O$. lacteum Mspl AFLP multi-locus profiling collected at five sites in the CEZ with different soil total earthworm dose rates.

Figure 3. (Panel A) Percentage of methylated susceptible loci for $O$. lacteum collected at five sites in the CEZ with different soil total earthworm dose rates $(\mu \mathrm{Gy} / \mathrm{h})$; and, (Panel B) principle coordinate analysis for Mspl/Hpall meAFLP analysis for methylation loci for $O$. lacteum Mspl AFLP multi-locus profiling collected at five sites in the CEZ with different total soil earthworm dose rates.

Figure 4. Non-metric multidimensional scaling plot of 16S rRNA gene sequence analysis of gut microbiomes of $O$. lacteum collected at five sites in the CEZ with different total soil earthworm dose rates and the relationships with environmental vectors oriented in the direction of greatest increase with length is proportional to their correlation with the two NMDS axes.

Figure 5. Diversity of bacterial sequenced OTUs within the earthworm microbiome for O. lacteum collected from five locations within the CEZ expressed as Fischer's alpha in relation to soil $(A) \mathrm{pH}$ and $(B)$ loss on ignition, bars are shaded according to earthworm dose rate ( $\mu \mathrm{Gy} / \mathrm{h})$. 
Fig. 1

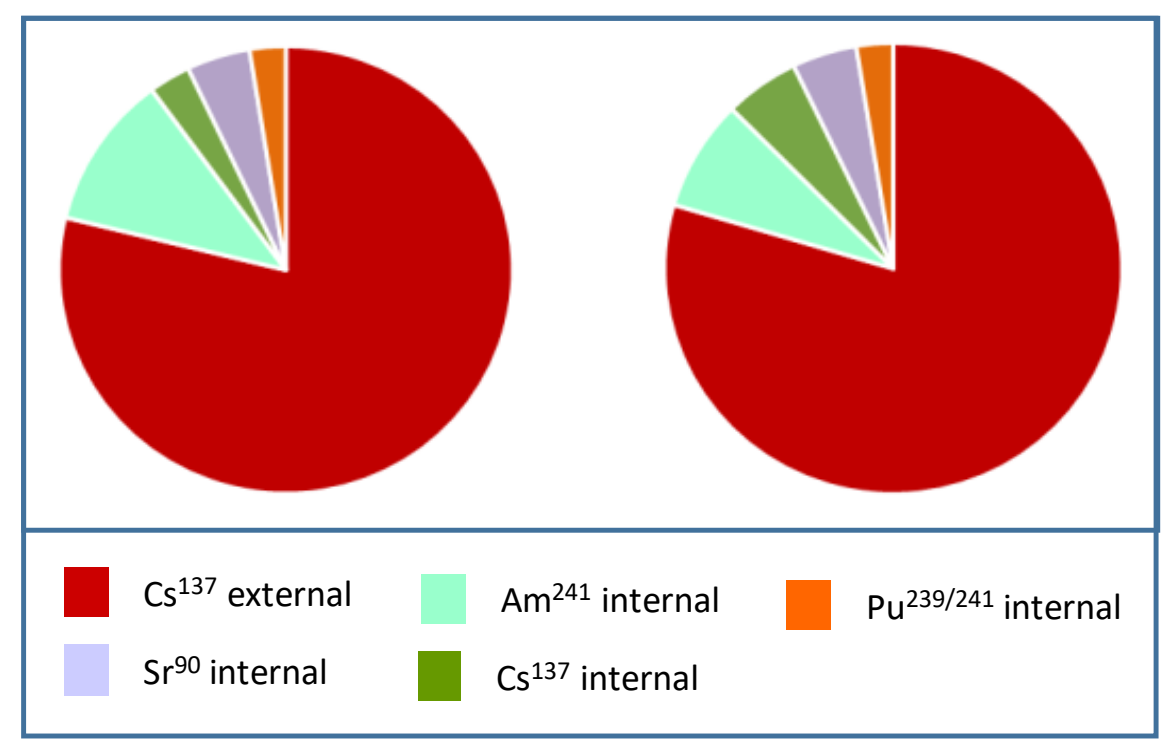


Fig. 2

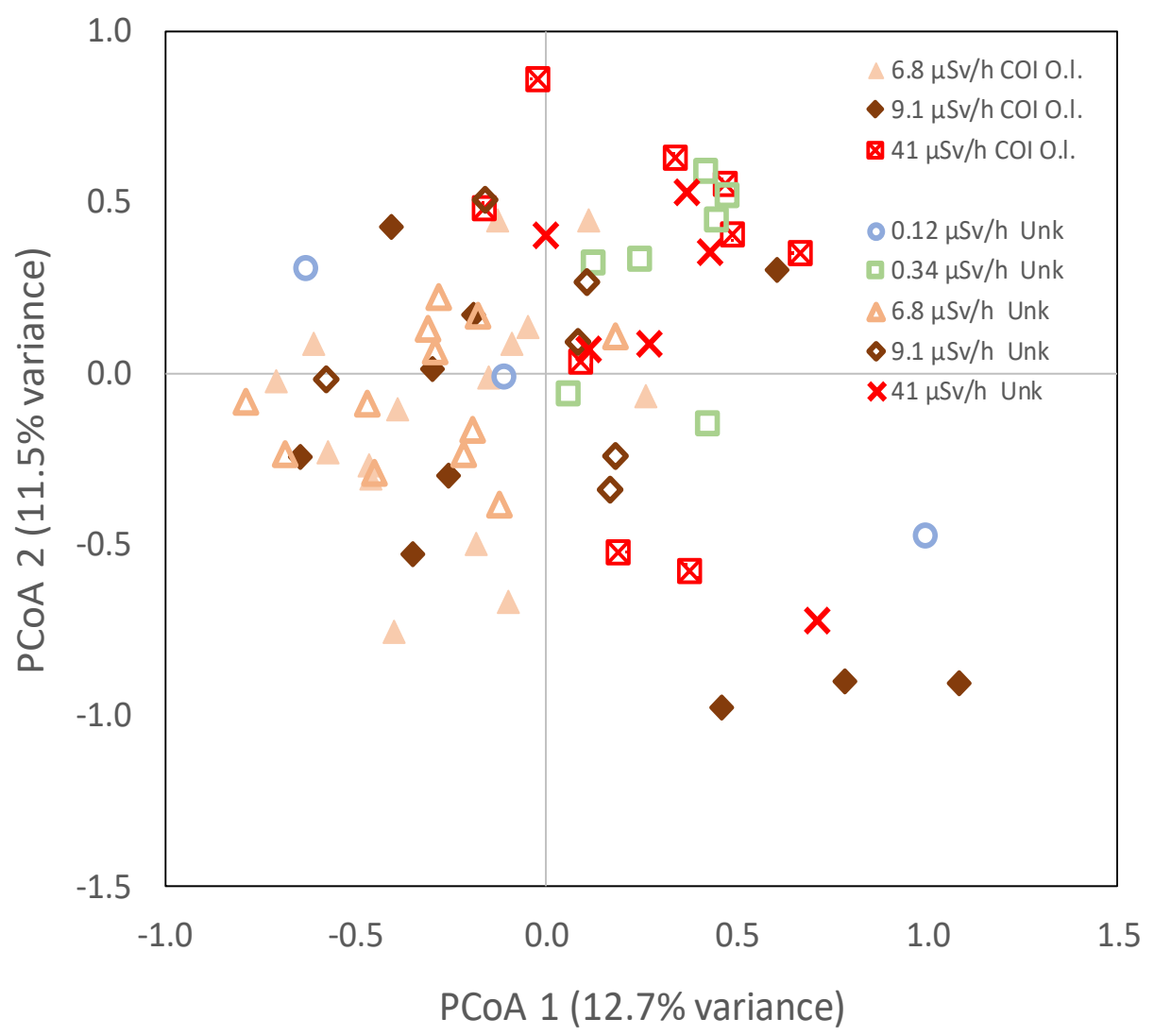


Fig. 3

A

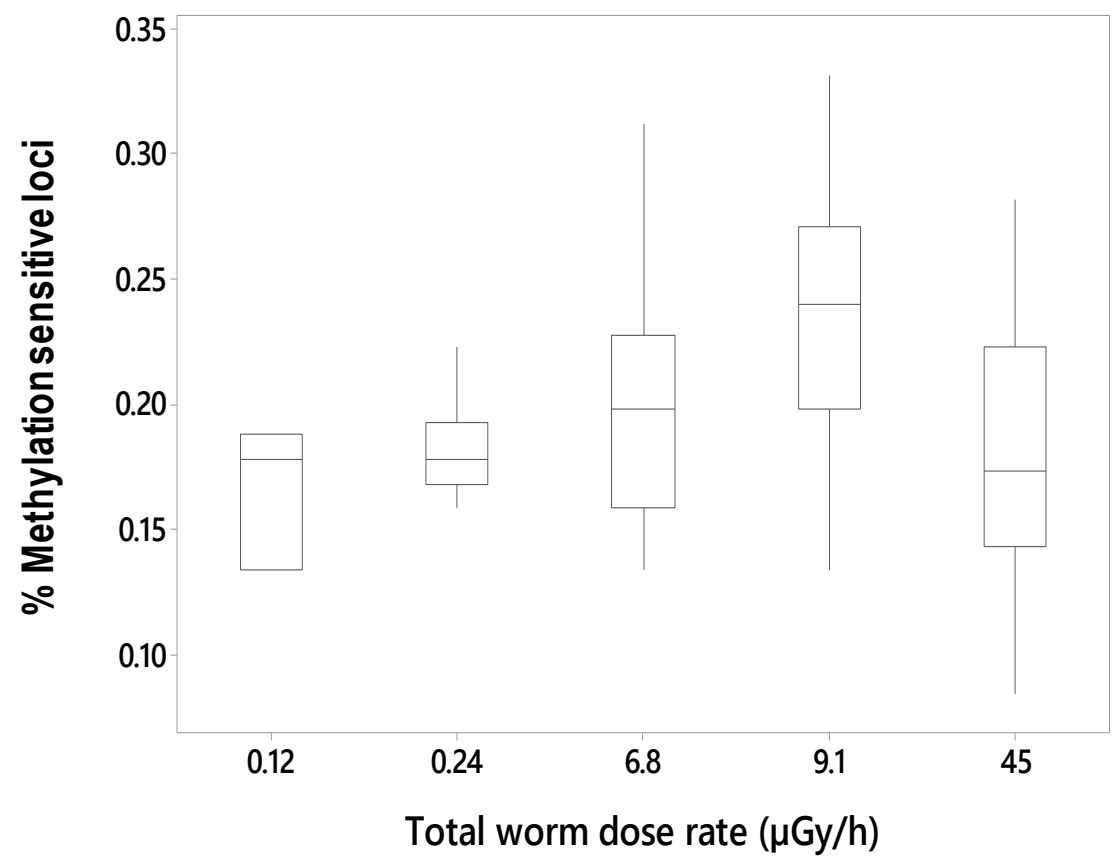

B

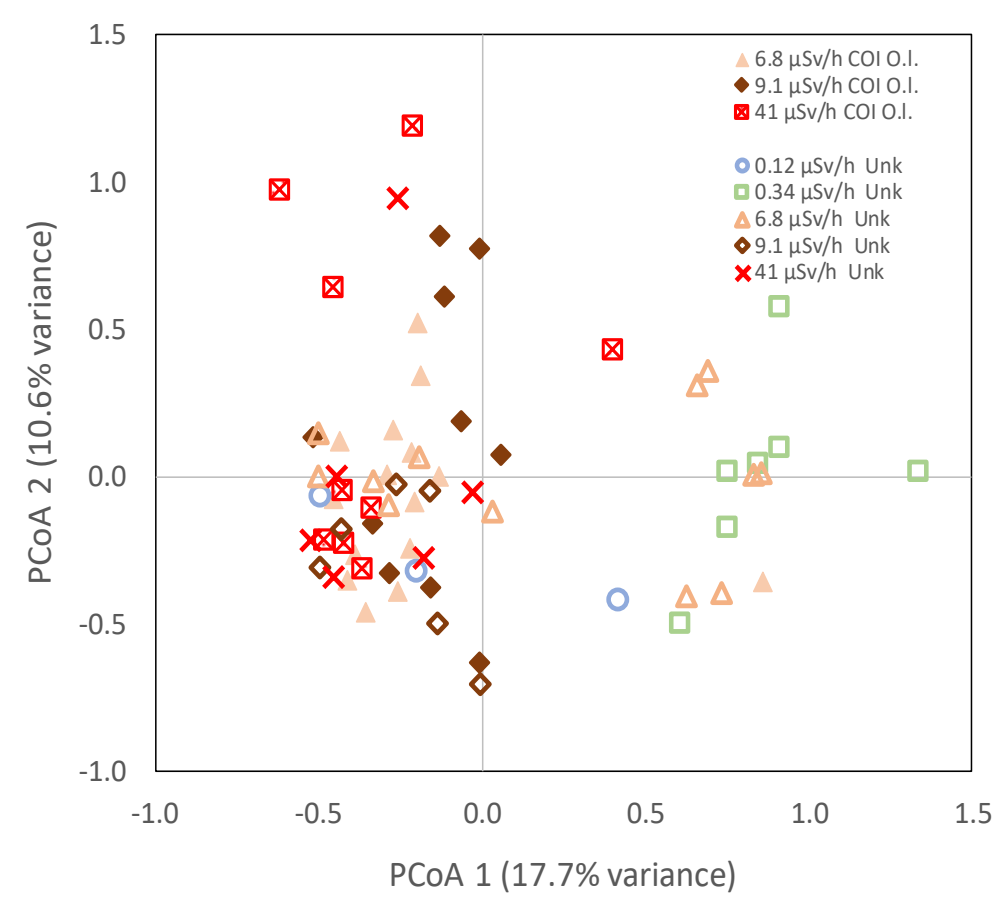


Fig. 4

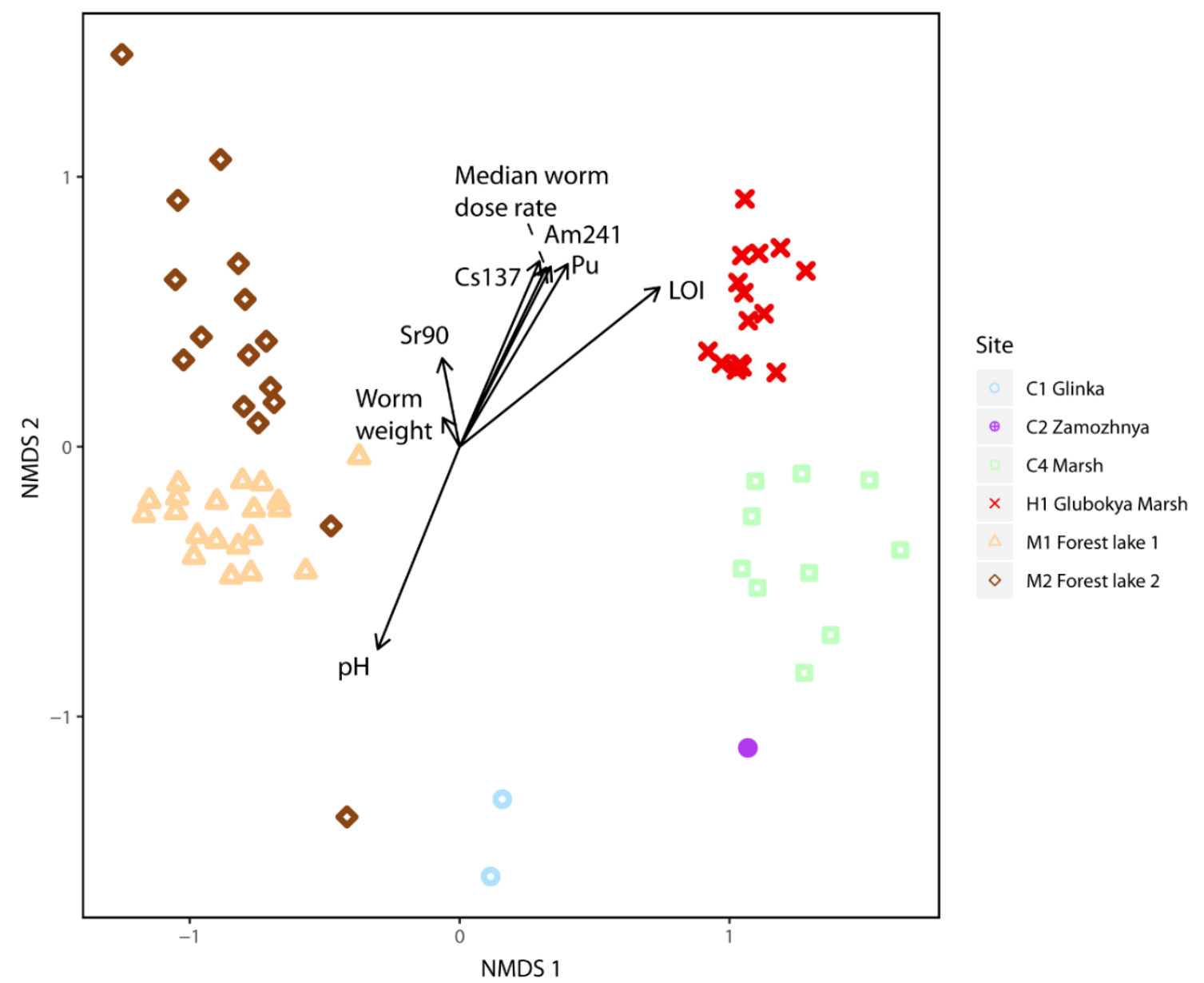


Fig. 5
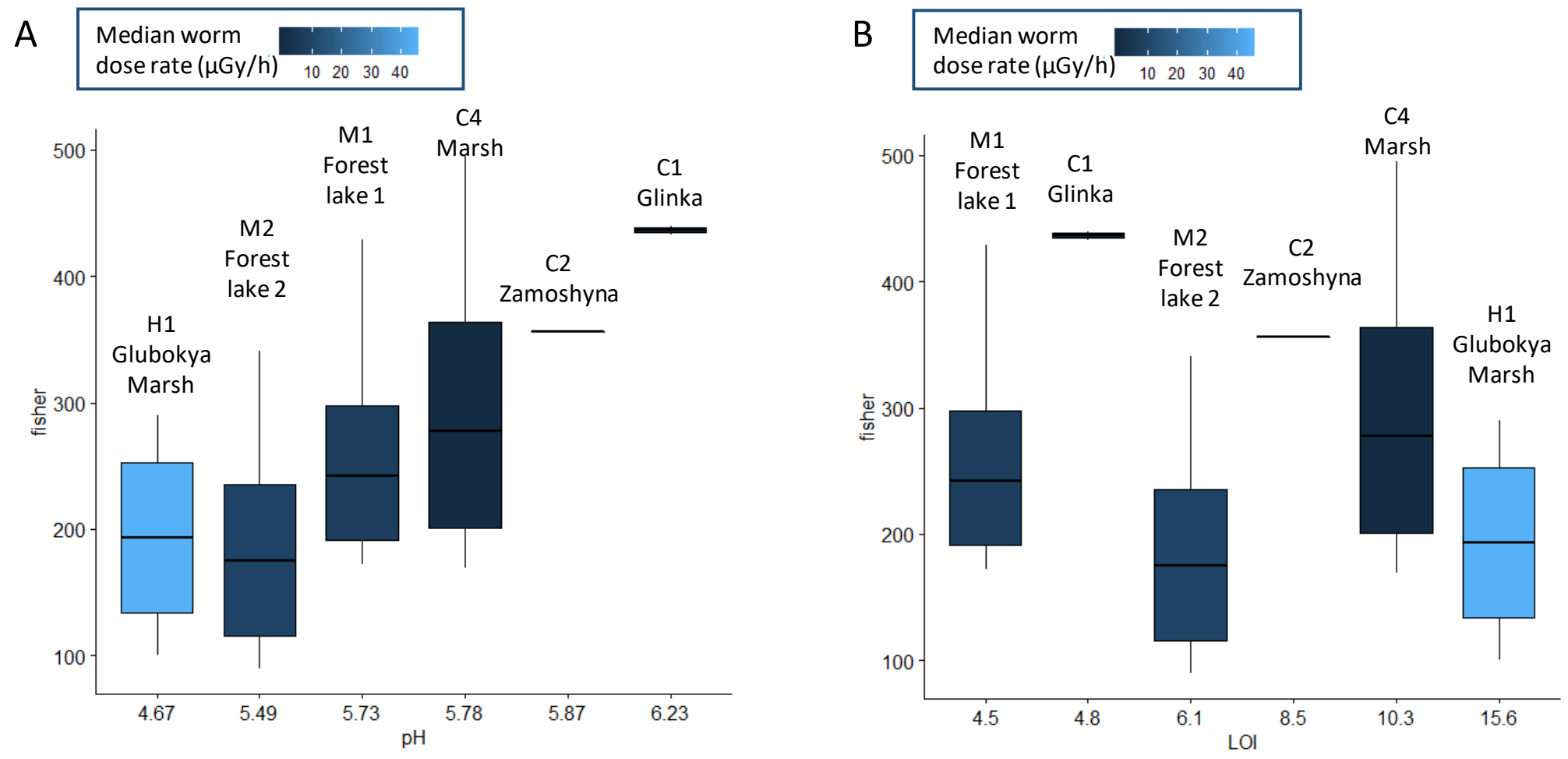
Supplementary Figure 1. Principle coordinate analysis of AFLP Mspl multi-locus profiles for morphotype $O$. lacteum and $A$. caliginosa: morphotype $A$. caliginosa confirmed by $\mathrm{COI}$ sequencing cluster to the right; morphotype $\mathrm{O}$. lacteum both confirmed by $\mathrm{COI}$ sequencing and which also fail to amplify for the COI locus cluster to the left as a single group.

Supplementary Figure 2. Phylogenetic gene tree showing the relationships between individual collected earthworms successfully amplified and sequenced for the Cytochrome oxidase I loci; branch distance indicates the degree of base substitutions between individual; all samples labeled starting P1 or P2 correspond to study samples with all other samples corresponding to reference specimen sequences.

Supplementary Figure 3. Relationship between NMDS axis 1 score and soil (A) median earthworm dose rate $(\mu \mathrm{Gy} / \mathrm{h}),(\mathrm{B}) \mathrm{pH},(\mathrm{C})$ loss on ignition and NMDS axis 2 score and soil (D) median earthworm dose rate, $(E) \mathrm{pH},(F)$ loss on ignition. 